Vol. 8, n² | 2004

Varia

\title{
Ricardo D. Salvatore, Wandering Paysanos. State Order and Subaltern Experience in Buenos Aires During the
} Rosas Era

Durham and London, Duke University Press, 2003, 524 p., ISBN 08223

30865

Ruth Stanley

\section{(2) OpenEdition}

\section{Journals}

Electronic version

URL: https://journals.openedition.org/chs/471

DOI: $10.4000 /$ chs. 471

ISSN: 1663-4837

Publisher

Librairie Droz

Printed version

Date of publication: 1 November 2004

Number of pages: 163-166

ISBN: 2-600-00803-5

ISSN: $1422-0857$

Electronic reference

Ruth Stanley, "Ricardo D. Salvatore, Wandering Paysanos. State Order and Subaltern Experience in Buenos Aires During the Rosas Era", Crime, Histoire \& Sociétés / Crime, History \& Societies [Online], Vol. 8, n² 2004, Online since 20 February 2009, connection on 23 March 2022. URL: http://

journals.openedition.org/chs/471; DOI: https://doi.org/10.4000/chs.471

This text was automatically generated on 23 March 2022.

(C) Droz 


\section{Ricardo D. Salvatore, Wandering Paysanos. State Order and Subaltern Experience in Buenos Aires During the Rosas Era}

Durham and London, Duke University Press, 2003, 524 p., ISBN 08223

30865

Ruth Stanley

\section{REFERENCES}

Ricardo D. Salvatore, Wandering Paysanos. State Order and Subaltern Experience in Buenos Aires During the Rosas Era, Durham and London, Duke University Press, 2003, 524 p., ISBN 0822330865

1 In this impressive book, Ricardo D. Salvatore draws on a wide range of sources including military records, legal archives, official correspondence and popular poetry to reconstruct subaltern experience during the supremacy of Juan Manuel de Rosas within the Argentine Confederation. Following a period of unrest and civil war after independence, Rosas assumed the Presidency of the Confederation in 1829 and apart from a brief interlude, reatined power until 1852, when defeat at the Battle of Caseros forced him into exile in England. Ostensibly, the dispute between Rosas and his political opponents centred on the form of political organisation of the new state - whether it should be a unitary state, as Rosas' opponents (the unitarios) desired, or a federalist structure, as Rosas and his adherents (the federales) believed. Comingling with this conflict were distinct conceptions of the order and values of the new state, with the unitarios associated with European values and the pre-eminence of the urban gentry, and the federales representing Catholicism, tradition, and rural interests. Following Rosas' defeat at Caseros, his regime was decried by his political adversaries as a period 
of utter barbarity, his rule allegedly depending on the blind obedience of the unenlightened masses, a view repeated by historians and one that has proved hard to shake. By analysing in detail the experience of these subalterns, Salvatore provides both an impressive example of subaltern studies and a revision of the widely accepted view of Rosas as a tyrant ruling in the interests of the great landowners and dependent on the support of an incoherent and barbaric rabble. Earlier works, including many of Salvatore's own, have already challenged the standard interpretation of Rosas, but probably few as comprehensively and persuasively as this study.

2 In his introduction, Salvatore acknowledges affinities of methodology and perspective with the project of subaltern history developed by Indian scholars such as Guha and Spival. While recognising the enormous difference between the postcolonial situations of India and Argentina, the author shares subaltern studies' "preoccupation for deconstructing the discourse of the dominant and for repositioning into history the voices and recollections of subaltern agents » (p. 7) - here, the last word quoted is immensely important, for a central element of this endeavour is indeed to discover the agency of subalterns. Adopting the subalternist perspective involves, for Salvatore, an awareness both of the representational nature of « evidence » about subaltern subjects and of the subalternity of the voice and claims of these subjects in relation to dominant discourse (FN 11, p. 430). The subalternist perspective implies a double corrective to elite history, countering both the lack of recognition of the role of subalterns and the excessively negative portrayal of subalterns as barbaric, violent, ignorant etc. (p. 8). Despite the avowedly fragmentary nature of the evidence available, Salvatore's brilliant analysis of political, social and economic relations, combined with detailed textual interpretation, succeeds wonderfully in reconstructing subaltern experience. Adapating a phrase coined by feminist social science, this amounts to far more than simply « add subalterns and stir »- in other words, it is not merely an addition to, but rather represents a fundamental questioning of elite historiography.

3 Who are the subalterns whose experiences Salvatore reconstructs? They are the black population, both slaves and free, poor women, indigenous peoples, and above all the « class » of rural peons (neither a class in or for itself, but constructed as such through dominant discourse, as he points out), the itinerant rural labourers who travelled the countryside in search of work and to evade military service, and who give the book its title.Their experiences in four arenas are analysed: the economy, the law, the military and politics. Although these areas are analytically distinct, in practice they fed into each other, and throughout the book Salvatore points to these interconnections. Thus, one of the functions of the penal system was to provide manpower for the regular army, which largely consisted of conscripted felons. On the other hand, despite its coercive nature, military sevice was conceived by soldiers as having a contractual basis. Conversely, military requirements prompted the introduction of an effective welfare system for the rural poor and stimulated the rural economy.

4 Salvatore's painstaking reconstruction of the role of subalterns in these areas shows the wandering paysanos and other plebeian elements to have been actively involved in negotiating their relationship with the state, pressing demands, articulating rights, and resorting to subterfuge and deception to escape the burdens of serving the war machine. Thus, he argues that the system of rural poor relief, essentially consisting in supplies of meat and firewood, originally responded to military demands: those serving in the federal armies had to be assured that their womenfolk were not suffering. Yet 
this instrumental approach to welfare developed into a permanent feature of the Rosas regime - what began as a paternalistic gesture was converted into a state obligation through the insistence of poor women on the continued delivery of subsidies (pp. 48-49), leading to a notable improvement in the conditions of livelihood and nutrition of the rural poor. Even within the army, convicted felons whose punishment was a term of military service did not conceive of themselves as without rights. Miserable though conditions of service often were, they were not accepted without demur: conscripts resorted to a range of stratagems to improve their lot. In an era of chronic manpower shortage, one of the most effective was what Salvatore terms « bargaining by threat of desertion». Deserters would sometimes band together and negotiate their re-entry into the army, often under a new commander.

5 Perhaps the area where Salvatore most effectively challenges established wisdom is in his detailed reconstruction of the legal system and the nature of crime under Rosas. Rosas described himself as the "Restorer of the Laws", yet, as Salvatore remarks (p. 161), there is a consensus among historians that his regime lacked a credible system of justice, a view supported by the confiscation of unitario propety and the terror unleashed against political opponents, the use of summary proceedings, the abuse of judicial discretion, and the concentration of power in the hands of the dictator. Salvatore does not call these elements into question, but succeeds in painting a far more differentiated picture of the role of law, which was indeed « a crucial element of the order » envisaged by Rosas (p. 164). He argues that the peculiarities of the legal system can be explained by a specific conception of law that combined expediency and duress with respect for legal procedures. That lay justices of the peace were regularly exhorted by Rosas to keep themselves informed of, and to apply with impartaility, laws and legal procedure, that they kept archives « in the middle of the pampas » and copied out decrees « at candelight» (p. 177) speaks to Rosas' conviction that legality was an essential aspect of the order he imposed. Exemplary punishments were part of the pedagogy of the law, Salvatore concedes, but so too were public readings and proclamations to inform a largely illiterate population of their legal rights and duties and the distribution of newspapers among representative citizens who were expected to pass on information to their neighbours. He suggests that appeals for review of manifestly unfair judicial decisions show that there was a strong belief in justice among middling and poor paysanos, in part because they made concrete gains in this sphere under the regime of Rosas: better-functioning institutions provided subalterns with improved chances to redress situations of injustice, corporal punishment - including of slaves by their masters - was more closely controlled, and lower-class women could substantiate criminal indictments. Contrary to the established view, the great cattle ranch or estancia, with its supposedly feudal power structures and privatised law enforcement, was not the model for Rosas' conception of law; rather, equality before the law was a tenet of this conception. Salvatore's description of state officials invading the ranch of Nicolás Anchorena, a cousin of Rosas and reputedly one of the greatest landowners in the country, to apprehend deserters and common criminals being sheltered there (p. 173), provides an effective counterpoint to the notion of a feudalised system of justice.

6 However, this is not to say that equality before the law was achieved in practice, and Salvatore shows how state imperatives, neighbours' prejudices, and social conflicts combined to produce the statistics on crime that he analyses in chapter 6 . The construction of crime as reflected in the data he examines is inseparable from the 
voracious appetite of the army for new recruits: drawing on local records over a twenty-year period (1831-1851), Salvatore finds "crimes against the state »illegalities surrounding military service - to represent the largest single category, and within it, desertion from the army and travelling without proper identification to be the most common violations of the law. He concludes that the "two great illegalities " (p. 214) affecting the countryside were theft and desertion, often related, since deserters needed to steal horses and riding apparel in order to make good their escape. Knife fights, supposedly endemic among the savage gauchos, do not figure prominently in the data, although Salvatore concedes that this may be a statistical artefact. Crimes against public order were also rare in this period, either because Rosas made good his aspiration to restore order to the countryside, or because of underreporting, or, probably, a combination of both factors (p. 215). In sum: against the popular view that the province of Buenos Aires was characterised by high levels of inter-personal violence and disorder in this period, Salvatore offers a compelling interpretation that places the creation of crime squarely in the context of the requirements of a state at war: « Rather than engage in a war against property owners or decimate themselves in the defense of honor, poor paysanos were involved in a quotidian confrontation with the state around the issue of military service. The state of Buenos Aires, preoccupied with manning its armies, had criminalized the customary activities of peasants and laborers (including the direct appropriation of cattle and horses) and punished law breakers with long terms in the army. The rural poor responded in kind, avoiding militia registration, shirking regular military sevice, and deserting the army when conditions became intolerable. To remain out of the reach of military recruiters and the rural police, poor paysanos put into practice multiple 'arts of deception': forging passports, permits, and release papers; hiding their uniforms; changing names; seeking refuge among relatives and friends; keeping their past to themselves; changing jobs frequently» (p. 217). Thus, a legal system predicated on the concept of social equality actually produced discrimination, as the power of the law fell most heavily on those who shared the appearance of poor paysanos and had no fixed residence (p. 220) - not least because local law enforcement viewed such transients with suspicion, making of them a « convenient other " and choosing them to fill the local quotas of men provided to the military (p. 206). In effect, Salvatore identifies a dual nature of the legal system, consisting at the local level of a kind of communal justice reflecting the suspicions and prejudices of the local community, an approach that existed alongside the more systematic treatment of serious crime. The wandering paysanos bore the brunt of this duality.

7 In sum, this book offers an immensely detailed reconstruction of subalterns engaged in acts of subterfuge and negotiation, claiming rights or resorting to deception according to circumstances. Salvatore's analysis is rich and nuanced. The peculiar relationship between the Rosista state and the wandering poor is not glorified; their marginality to the rituals of federalism is captured in the poignant description of festivities that excluded transients except as forced contributors of military sevice, «guarding from outside the joy of others, awaiting the opportunity to desert » (p. 393). Yet Salvatore also argues that as soldiers, poor paysanos became part of the political community in a way that was later denied to them. If the gauchos «disappeared» in the following decades, this was in part because their voices "disappeared from the official script " (p. 419). This observation encapsulates some of the ambiguities of subaltern experience in the Rosas era that are so sensitively analysed in this work: as potential army recruits, 
wandering paysanos were an object of obsession for the state authorities, whose records provide an immense wealth of detail on the lives of the poor. Though they sought to evade military service, the wandering poor became political subjects through their involvement in the federal armies, gaining a visibility, both for the state and historians, that did not outlast the fall of Rosas. One minor quibble: colour played a crucial role in federalist symbolism, scarlet clothing and adornments (of both horse and rider) being an outward mark of adherence to the federalist cause. It is to be regretted that this beautifully-produced book includes no colour illustrations, and that the reader has to rely on the author's elucidation (pp. 134, $143,147)$ of the images reproduced here only in black and white.

\section{AUTHORS}

\section{RUTH STANLEY}

FU Berlin, Germany, rstanley@zedat.fu-berlin.de 